\title{
Applying analytic hierarchy process (AHP) to identify decision-making in soybean supply chains: a case of Mato Grosso production
}

\author{
Aplicando o processo de hierarquia analítica (AHP) para identificar a \\ tomada de decisão na cadeia de suprimentos da soja: um estudo de \\ caso da produção em Mato Grosso
}

Rodrigo Carlo Toloi ${ }^{1,2}$ (D), João Gilberto Mendes dos Reis ${ }^{2}$ (D), Marley Nunes Vituri Toloi ${ }^{1,2}$ (D), Oduvaldo Vendrametto ${ }^{2}$ (D), José António Sarsfield Pereira Cabral ${ }^{3}$ (B)

\begin{abstract}
${ }^{1}$ Instituto Federal de Mato Grosso (IFMT), Rondonópolis (MT), Brasil. E-mails: rodrigo.toloi@roo.ifmt.edu.br; marley.toloi@roo.ifmt.edu.br ²Programa de Pós-graduação em Engenharia de Produção, Universidade Paulista (UNIP), São Paulo (SP), Brasil.

E-mails: joao.reis@docente.unip.br; oduvaldo.vendrametto@docente.unip.br

${ }^{3}$ Departamento de Engenharia e Gestão Industrial, Faculdade de Engenharia, Universidade do Porto (UP), Porto, Portugal. E-mails: jacabral@feup.pt
\end{abstract}

\begin{abstract}
How to cite: Toloi, R. C., Reis, J. G. M., Toloi, M. N. V., Vendrametto, O., \& Cabral, J. A. S. P. (2022). Applying Analytic Hierarchy Process (AHP) to identify decision-making in soybean supply chains: a case of Mato Grosso production. Revista de Economia e Sociologia Rural, 60(2), e229595. https://doi.org/10.1590/1806-9479.2021.229595
\end{abstract}

\begin{abstract}
This paper aims to identify and analyze the factors that influence the decision of Mato Grosso's farmers to produce soybean using the Analytic Hierarchy Process (AHP). We found evidence that decisionmaking of soybean production is related to rural production aspects such as climate, financing, cost of inputs, and soil quality rather than marketing and logistics. The novelty of this paper is the empirical analysis of the decision-making in agricultural production using AHP. The decision model was created and tested considering 21 farmers and 19 experts linked to the soybean production. Three different scenarios were considered: farmers' view, experts' view, and combined view. Our findings indicate that farmers and experts agree with rural aspects are predominant in the decision to plant soybean. Moreover, logistics have been used as an important flag of soybean competitiveness on international trade by soybean stakeholders in Brazil. However, our results show that logistics impact in the soybean decision-making process is low. Due to data limitation access, this study focuses only on Mato Grosso. However, this study has an exploratory character and presents empirical results that may help to understand soybean production over the country.
\end{abstract}

Keywords: Analytic Hierarchy Process - AHP, soybean production supply chains, agricultural production, decision-making, food production.

Resumo: Este artigo tem como objetivo identificar e analisar os fatores que influenciam a decisão dos agricultores de Mato Grosso em produzir soja usando o processo de hierarquia analítica (AHP). Encontrouse evidências de que a tomada de decisão da produção de soja está relacionada a aspectos da produção rural, como clima, financiamento, custo de insumos e qualidade do solo, em vez de comercialização e logística. A novidade deste artigo é a análise empírica da tomada de decisão na produção agrícola usando AHP. O modelo de decisão foi criado e testado considerando 21 agricultores e 19 especialistas vinculados à produção de soja. Três cenários diferentes foram considerados: visão de agricultores, visão de especialistas e visão combinada. Os resultados indicam que os agricultores e os especialistas concordam que os aspectos rurais predominam na decisão de plantar soja. Surpreendentemente, a logística apresentou baixo impacto na tomada de decisões, mesmo sendo usada como uma bandeira da competitividade da soja brasileira no comércio internacional. Devido ao acesso limitado de dados, este estudo focaliza apenas o estado de Mato Grosso, no entanto o trabalho tem um caráter exploratório e apresenta resultados práticos que podem vir a auxiliar o entendimento do processo decisório da soja produzida no Brasil.

Palavras-chave: processo de hierarquia analítica, cadeia produtiva da soja, produção agrícola, tomada de decisão, produção de alimentos. 


\section{Introduction}

The world population is expected to reach 9.7 billion by 2050 (United Nations Department of Economics and Social Affairs, 2019) increasing the demand for agricultural products. One of the primary global agricultural commodities is soybean, consumed as natural grain, like oil, and meal for animal protein industry.

Currently, Argentina, Brazil, and the US are responsible for around $81 \%$ of global production (United States Department of Agriculture, 2020). Among them, Brazil has the highest growth in crop area, production volume, and international trade share (Brasil 2020; United States Department of Agriculture, 2020). The Brazilian 2019/2020 harvest accounted for 124.8 million tons covering 36.9 million hectares (Brasil, 2020). For this reason, Brazil is considered one of the biggest food producers at the global level (Contini, 2010). However, Reis et al. (2016) report that soybean production in the country faces enormous challenges, including scarcity of transportation logistics and storage capacity (Lipinski et al., 2013), long distances between the production areas and the ports used for export (Vilhena \& Ribeiro, 2015; Reis et al., 2016), strong dependence on imported fertilizers (Teixeira et al., 2013; van Tongeren et al., 2014; Raucci et al., 2015), environmental, social, and economic issues (Zhu \& Sarkis, 2004; Cavalett \& Ortega, 2009; Soares, 2016; Toloi et al., 2018).

There is a common ground that all these challenges affected the decisions of producers and trading companies regarding soybean planting, marketing, and distribution. Therefore, the decision-making process in agricultural activity should consider information related to the value chain, the upstream, internal, and downstream chains (Oliveira \& Pereira, 2009).

Having said that, in the case of soybean producers, the literature indicates that decisions are commonly made according to their perception of risk, available resources, perceived capacity, and external support (Singh et al., 2016). Agricultural decisions are made considering the pressure from multiple variables that are directly and indirectly related to soybean production, such as the adoption of technologies (Rupnik et al., 2018), economic and political aspects at the local and global levels (Puchalsky et al., 2018), production volumes (Goldsmith, 2008), production systems (Fountas et al., 2006), climate, selection of suppliers (Arvor et al., 2010), availability of inputs (Associação Nacional para Difusão de Adubos, 2017), and available logistics (Reis \& Leal, 2015).

Despite the idea that decision-making is a core issue in agricultural management and revolves around many variables (Fountas et al., 2006), there is a lack of studies investigating whether the decisions in agricultural production are made as presented in the literature. Besides, there are doubts about whether the decisions consider these different variables.

Given these issues, this study aims to analyze which factors affect the decision-making of Brazilian farmers regarding soybean production. The sample of this paper is represented by 21 farmers located in Mato Grosso, the largest state producer, and 19 experts of the soybean chain. Despite the sample of this research, we could measure the empirical evidence of the decision-making factors considering a multicriteria analysis environment.

We created a decision tree to apply the analytic hierarchy process (AHP) methodology (Saaty, 1980), which includes hierarchizing a set of variables based on weighted criteria to improve the decision-making process. The variables were established based on the literature divided into three categories: rural production, logistics, and marketing.

The remainder of this paper is organized as follows. After this introduction, section 2 presents the study theme. In section 3, the decision-making process for rural properties is contextualized. Section 4 describes the method of data analysis. Section 5 describes the methodological steps that have been followed to explain how the study was developed. Section 6 shows the results and the respective analysis. Finally, section 7 presents the final considerations, including study limitations and suggestions for future studies. 


\section{Literature Review}

\subsection{Mato Grosso}

The State of Mato Grosso is located in the Central-West region of Brazil, in the southern part of the South American continent (latitude $13^{\circ} \mathrm{S}$ and longitude $56^{\circ} \mathrm{W}$ ). It encompasses 903,207.19 $\mathrm{km}^{2}$ and its neighboring states are Pará and Amazonas to the north, Mato Grosso do Sul to the south, Goias and Tocantins to the east, and Rondônia to the west (Instituto Brasileiro de Geografia e Estatística, 2020a). The location of the state on the Brazilian map and the percentual of soybean production in 2019/20-year crop can be seen in Figure 1. Figure 2 compares the evolution of production per municipality between 1994 to 2019.

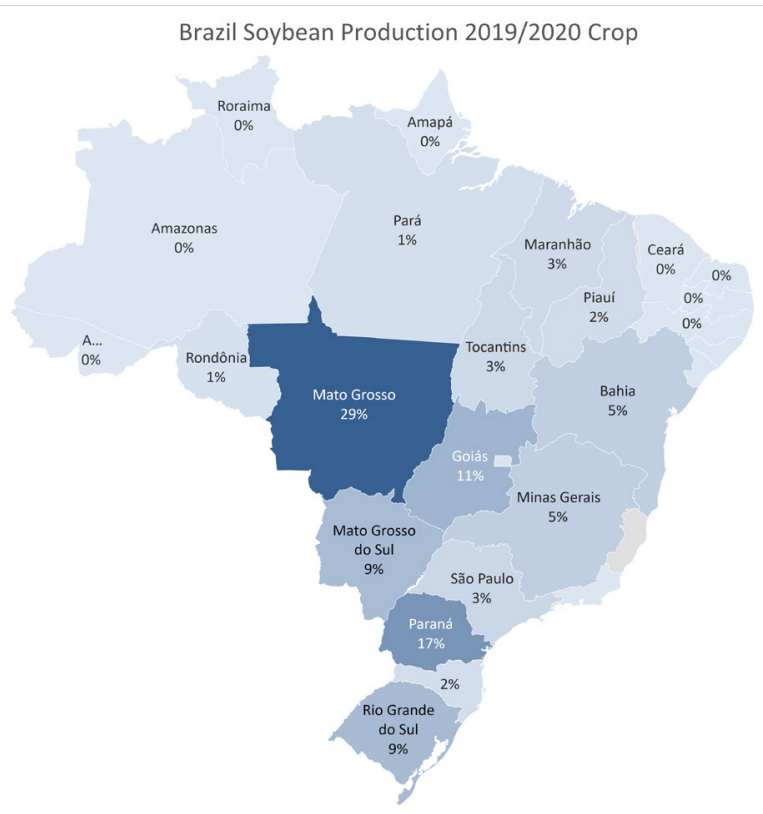

Figure 1. Mato Grosso location and percentual of Brazilian soybean production in 2019/2020-year crop. Source: Adapted from Brasil (2020)

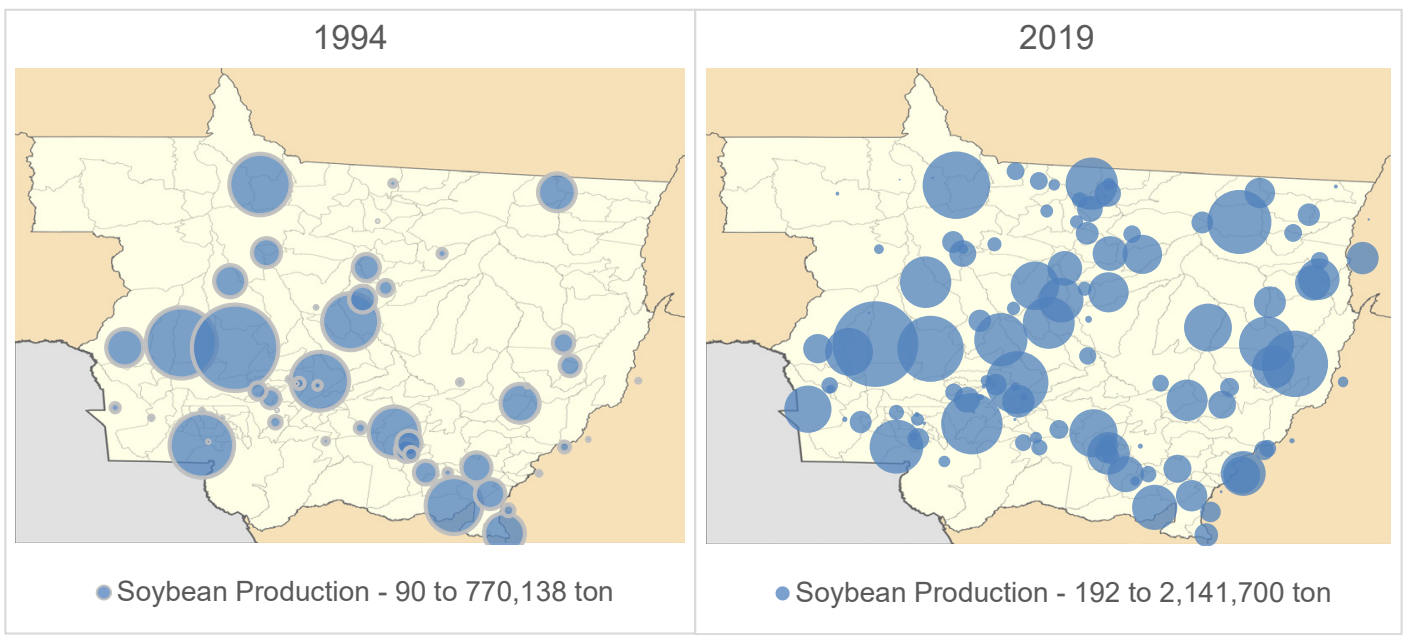

Figure 2. Evolution of Mato Grosso production per municipality. Source: Adapted from Instituto Brasileiro de Geografia e Estatística (2020b). 
We note that Mato Grosso is the main producer of soybean in Brazil and soybean is overspreading into the state. In the 2019/2020 harvest, it accounted for $27.1 \%$ of the entire area used for soybean production in the country, producing 35.8 million tons, equivalent to 29.0\% of the national production (Brasil, 2020).

The main production activities in Mato Grosso are linked with agribusiness being the first place in national production of cotton, corn, the herd of beef cattle, soybean, and sunflower producing an area of 17 million hectares (Instituto Mato-grossense de Economia Agropecuária, 2020)

Since the introduction of soybean in Mato Grosso, the crop area has always increased, particularly owing to the wide availability and low cost of land (Goldsmith \& Hirsch, 2006), Figure 3.

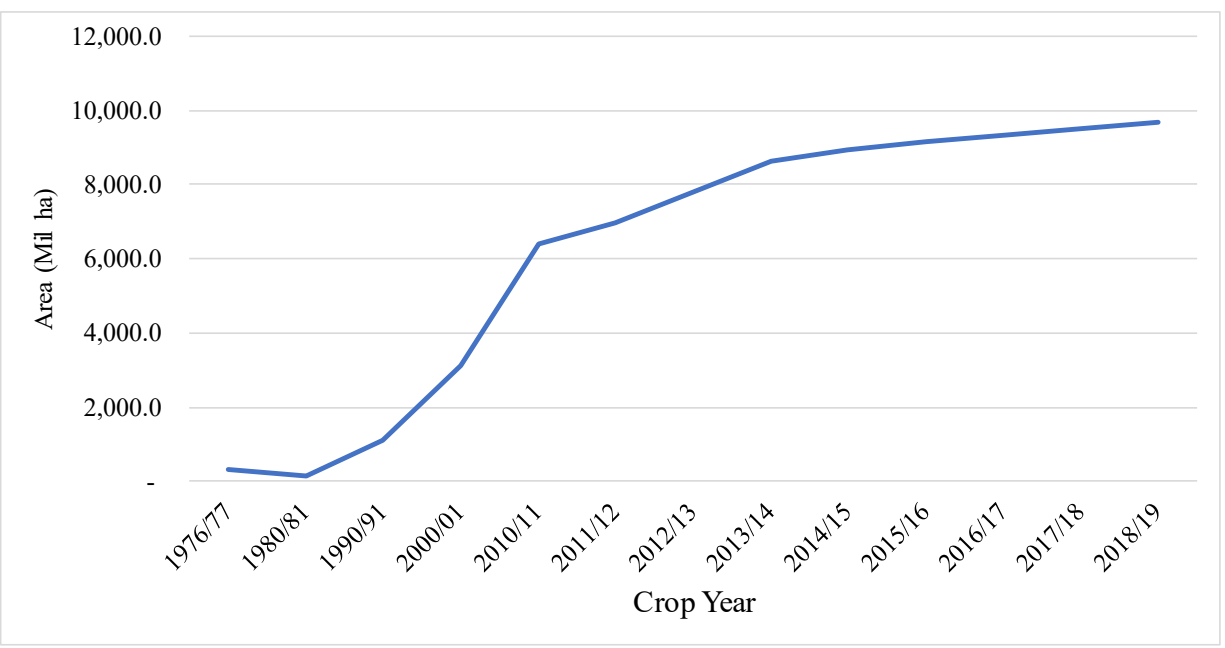

Figure 3. Expansion of soybean crop area in the state of Mato Grosso between 1976 and 2020. Source: Adapted from (Brasil, 2020).

Arvor et al. (2010) also reported that the expansion illustrated in Figure 2 was a consequence of the adoption of public policies, financing of agro-industrial projects, wood logging, and trading companies that started operating in the area.

Of the soybean 2019/20 harvest in Mato Grosso, 29.4\% was commercialized in the state internal market, $8.4 \%$ interstate market, and 62.4 was for exportation (Instituto Mato-grossense de Economia Agropecuária, 2019), Figure 4. Moreover, the soybean sells in the internal market $76 \%$ for soybean meal and 20\% for oil (Instituto Mato-grossense de Economia Agropecuária, 2019).

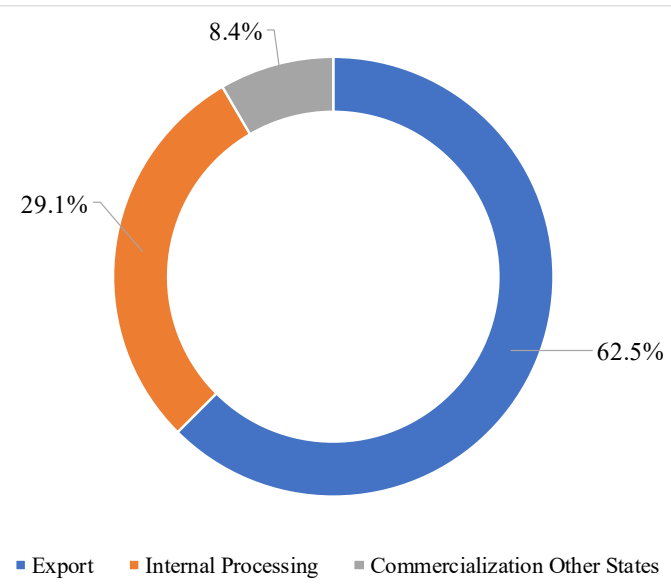

Figure 4. Use of soybean produced in Mato Grosso. Source: Adapted from Instituto Mato-grossense de Economia Agropecuária (2019). 
Figure 3 showed that exports remain the primary market for soybean producers, reflecting the role of trading companies in buying soybean from producing countries and reselling it to the world market, thereby promoting an extremely globalized chain. Land costs and climate may be factors that help concentrate soybean production in a few countries.

\subsection{Soybean decision-making}

Because of the complexity of agribusiness, farmers often make decisions based only on personal intellect, intuition, and expectation of favorable scenarios for their activity. However, this guidance is useful only to create ideas and foresee scenarios (Fountas et al., 2006).

Decision-making is a core question in the management of soybean production. Soybean farmers must systematically think about their needs and consider the entire chain to identify the critical information that will help them make a decision. In this sense, they cannot ignore the use of technology to predict the production to develop their strategies (Abraham et al. (2020). However, soybean production has unique attributes that make it a complex business.

The decision-making process should be fast, and any change to a decision already made about technological and productive operations, management of production quality, distribution and use of physical, financial, and environmental resources (due to the biological character of the agricultural production activity) can lead to great losses (Kurlavičius, 2009).

A decision made by the producer based on empirical grounds that expects positive results still involves strong uncertainties. Cognition and intention based on experience, sociocultural influences, and beliefs are not enough for proper planning; market globalization, world inventory prices, environmental preservation, and pressure for food production, among other factors, should also be considered. Production is not an isolated act, it is a part of a network that starts with the decision to plant and ends with the consumption of the crop in the form of several final products (Singh et al., 2016).

In this complex scenario, making decisions regarding soybean production is still a new process, particularly in the Central-West region of Brazil. It is a poorly understood adaptive process. Studies have been conducted to provide a better understanding of the decision-making process in the field of extensive farming.

Singh et al. (2016) pointed out that some traditional approaches to understanding a soybean producer's decision-making and behavior were developed on a simplified and biased view, either an economic bias (where the man was a rational individual that acts to maximize profit) or an anthropological bias (agricultural choices seen as responsive to the decision-making environment). Thus, the decisions of farmers have been analyzed through specific theories, such as planned behavior, limited rationality, and innovation and adoption of agricultural systems (Rose et al., 2016; Rupnik et al., 2018).

Decision-making is a complicated process to summarize a concept, and its structure requires a logical and objective consideration of all decisive factors involved, which are usually obscure, qualitative, intangible, inexpressible, and subjective, making quantification difficult. Thus, to help understand the decision-making process of the soybean producers in Mato Grosso, this study used the AHP, which is discussed below.

\section{Methodology}

\subsection{Analytic Hierarchy Process}

The AHP was developed by Professor Thomas L. Saaty in the 1970s (Saaty, 1980, 2008). It seeks to divide the problem related to decision-making into various hierarchical levels. The 
highest level is focused on the problem to be solved and the intermediate levels are focused on the factors that influence the decision. Alternatives to the decision are at the lowest level. This way the elements of this hierarchical process are compared with each other (Saaty, 1980; Vilhena, \& Ribeiro, 2015).

For this comparison, Saaty (2008) proposed an absolute scale to compare the criteria, comparing the first with the second and determining how much more or less important it is concerning the second. The author suggests the use of a scale from 1 to 9 , defining values for each of the odd indices, and for intermediate situations, even values of 2 to 8 , as described in Table 1.

Table 1. Relative scale for paired comparison

\section{Intensity of importance Description}

Equal importance $\quad 1$ Both activities equally contribute to the objective.

Moderate importance 3 Weak or slight importance over another - Experience and judgment slightly favor one activity over another.

Strong importance

5 Greater or more essential importance when compared with another Experience and judgment strongly favor one activity over another.

Very strong importance

7 Very high or demonstrated importance - An activity is favored very strongly over another; its dominance is demonstrated in practice.

Extreme importance

9 Extremely high importance - The evidence favors one activity over another with the highest level of certainty.

Source: Adapted from Saaty (1980) and Granemann \& Figueiredo (2013).

Once the AHP model is constructed, the influence of all factors identified is determined by comparing two factors together in pairs and by comparing specific criteria and subcriteria.

In this sense, the matrix involves evaluating each alternative concerning the decision criteria. The matrix comprises $n$ criteria and $m$ alternatives (Granemann \& Figueiredo, 2013), as illustrated in Equation 1.

$\mathrm{A}=\left[\begin{array}{crcc}1 & \mathrm{a} 12 & \cdots & \mathrm{a} 1 \mathrm{n} \\ \mathrm{a} 21 & 1 & \ldots & \mathrm{a} 2 \mathrm{n} \\ \cdots & \ldots & \ldots & \ldots \\ \mathrm{an} 1 & \mathrm{an} 2 & \cdots & 1\end{array}\right]$

After the comparison in pairs, the inconsistency of the judgment of decision-makers is measured (Saaty, 1980). Equation 2 shows the inconsistency index.

$\mathrm{IC}=\frac{\lambda \max -\mathrm{n}}{\mathrm{n}-1}$

Where

$\lambda \max -\mathrm{n}=$ maximum eigenvalue;

$\mathrm{n}=$ matrix dimension.

The maximum inconsistency allowed to ensure reliability in the decision is $\mathrm{Cl}<0.1$. Above this level, the comparisons should be adjusted before moving on to the analysis of criteria.

Thus, the consistency ratio, according to Granemann \& Figueiredo (2013), can be obtained using the following Equation 3:

$\mathrm{CR}=\frac{\mathrm{CI}}{\mathrm{RI}}$ 
where:

$\mathrm{CR}$ is the consistency ratio of the answers from decision-makers;

$\mathrm{Cl}$ is the consistency index; and

$\mathrm{RI}$ is the random index calculated for square matrices of order $\mathrm{n}$ by the Oak Ridge National Laboratory, in the United States, being $1=0.00 ; 2=0.0 ; 3=0.58 ; 4=0.90 ; 5=1.12 ; 6=1.24$; and 7 = 1.32 (Saaty, 1980; Granemann \& Figueiredo, 2013).

Once the calculations have been made and an acceptable limit of inconsistencies has been set, to determine the weights for each group of criteria, subcriteria, and alternative, the answers from the producers must be compared between the preferred scenario and least recommended scenario.

In this context, when using the AHP for group decision-making, it is recommended that after collecting data of individual weights, the arithmetic mean values should be calculated as if they were a single value to prevent inconsistencies in the model.

\subsection{Decision model}

The first step to build the decision model using the AHP was to clearly define the objective so that the model would help in investigating factors that influence the decision of soybean producers regarding the productive, commercial, and logistics aspects of the reality of the situation in Mato Grosso.

The second step was to determine and categorize the criteria and subcriteria; however, this activity was possible only after extensively reviewing the literature on the productive, commercial, and logistics factors that influence the decision-making process of soybean farmers in Mato Grosso, Table 2.

The model has three factors related to the following criteria: marketing, logistics, and rural production. Marketing factors include aspects associated with reliability policy, price, and negotiation that involve the purchase of inputs, materials, and machinery required for planting. They also include the same aspects regarding soybean buyers. Logistics factors refer to the transportation and storage of inputs, materials, and machinery used in production and harvesting, and the short and long-distance transportation and storage of harvested soybeans. Rural production factors refer to aspects directly related to the production activity that influence soybean quality, productivity, and production cost.

Each group of criteria had a subcriteria that influenced the decision of soybean producers. The marketing group of criteria had the following subcriteria: price, negotiation, and reliability. The logistics group of criteria had storage and transportation as subcriteria, and the rural production criteria had the following subcriteria: agricultural financing, climate, soil quality, and cost of inputs. In addition to the criteria and subcriteria, alternatives were created in which the producer, the expert or both could select according to their best choice for the proposed scenarios.

The available alternatives included using the efforts and available resources to produce soybean, produce corn, or another agricultural activity (other than producing corn and soybean).

To validate the model, a pre-test was conducted with two producers and four experts related to soybean production, marketing, and logistics. Figure 5 shows the final decision tree of the model after the pre-test. 
Table 2. Literature review to define the factors of the AHP model

\begin{tabular}{|c|c|c|}
\hline Criteria & Factors & Author \\
\hline \multirow[t]{4}{*}{ Production (P) } & Soil quality & $\begin{array}{l}\text { Carauta et al. (2017); Yost et al. (2017), Congreves et al. } \\
\text { (2015), Choudhary et al. (2018), Santos et al. (2008); } \\
\text { Lacerda et al. (2015); }\end{array}$ \\
\hline & Climate & Arvor et al. (2010), Féres et al. (2011), Pires et al. (2016); \\
\hline & Cost of inputs & $\begin{array}{l}\text { Celio et al. (2014); Garrett et al. (2013); Singh et al. } \\
\text { (2016); Goldsmith (2008) }\end{array}$ \\
\hline & Agricultural financing & $\begin{array}{l}\text { Instituto Mato-grossense de Economia Agropecuária } \\
\text { (2019); Goldsmith (2008) }\end{array}$ \\
\hline \multirow[t]{2}{*}{ Logistics (L) } & Storage & $\begin{array}{l}\text { Arvor et al. (2010); Vieira \& Dalchiavon (2018); } \\
\text { Maia et al. (2013); }\end{array}$ \\
\hline & Transportation & $\begin{array}{l}\text { Kussano \& Batalha (2012), Martins et al. (2005); } \\
\text { Lipinski et al. (2013); Vilhena \& Ribeiro (2015); } \\
\text { Oliveira et al. (2016), Garrett et al. (2013); Goldsmith } \\
\text { (2008). }\end{array}$ \\
\hline \multirow[t]{3}{*}{ Marketing (M) } & Reliability & $\begin{array}{l}\text { Fountas et al. (2006); Singh et al. (2016); Turzi (2011), } \\
\text { Instituto Mato-grossense de Economia Agropecuária } \\
\text { (2019), Silva \& Lapo (2012); Kunitake \& Mota (2016), }\end{array}$ \\
\hline & Price & $\begin{array}{l}\text { Oliveira \& Pereira (2009), Gonçalves et al. (2014), } \\
\text { Goldsmith (2008) }\end{array}$ \\
\hline & Negotiation & Coelho (2000); Dias (2008), Colsera \& Henz (2000). \\
\hline
\end{tabular}

Source: Results of research (2018)

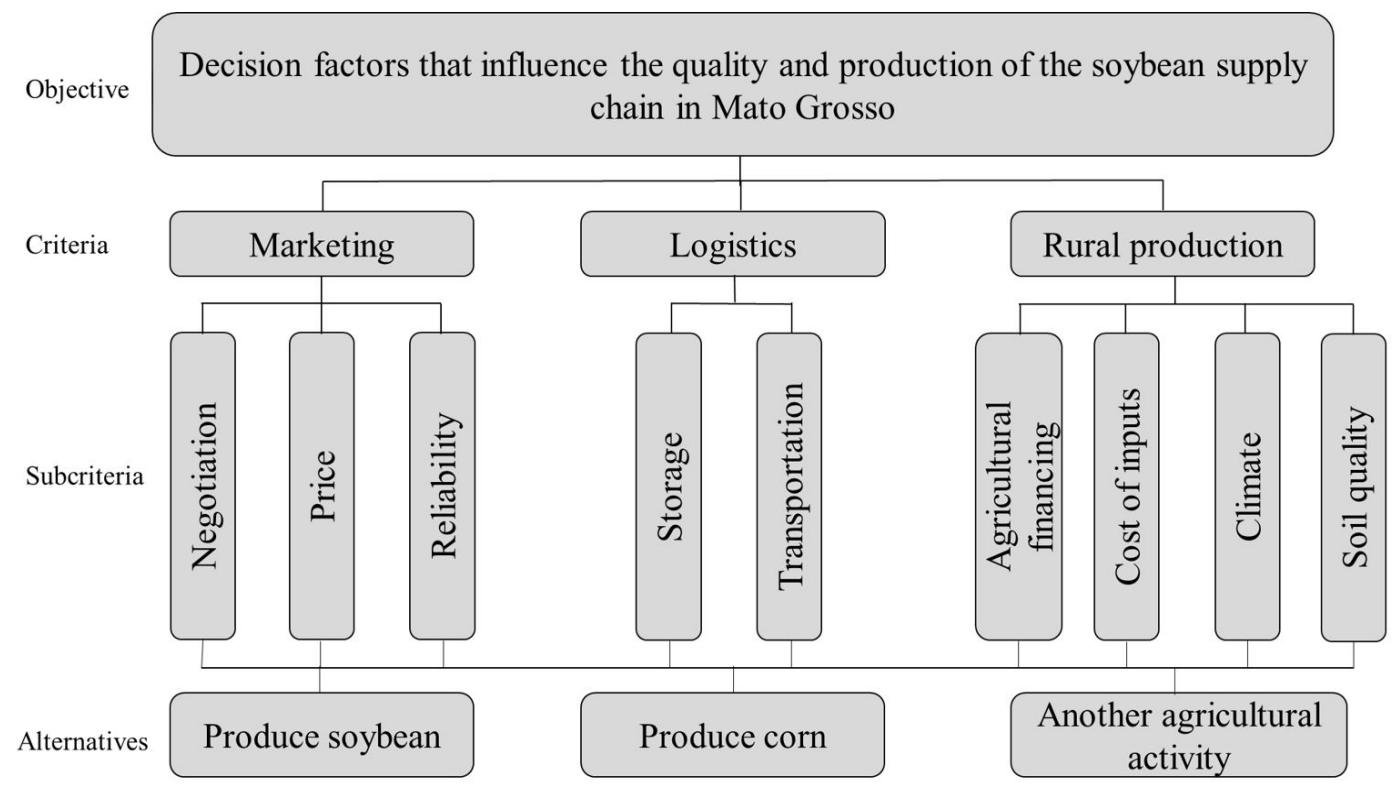

Figure 5. Hierarchical decision model for soybean production in Mato Grosso. Source: Results of research (2018).

\subsection{Data sampling}

To sample producers and experts responsible for decision-making in soybean production, this study used data on the number of soybean-producing properties in the State of Mato Grosso, obtained from the Brazilian Agricultural Census (Instituto Brasileiro de Geografia e Estatística, 2012). According to Instituto Brasileiro de Geografia e Estatística (2012), the state 
of Mato Grosso has 3,761 soybean-producing properties, which together cover 9.51 million hectares and produce 32.30 million tons of soybean.

Factors such as long distances, remote locations, and owners that are often not at the production farms made a study based on higher sampling unfeasible. Thus, this study chose to access as many properties as possible throughout the state.

Data collection was conducted in two stages. In the first stage, an electronic questionnaire was developed using the Google Forms ${ }^{\circledR}$ tool, and the link was sent by email to 70 experts who had experience in the field of soybean production and were linked to the financial sector, supply of inputs, research, marketing, and field technical support, as well as consolidated producers; however, only 6 questionnaires were answered, which reinforced the need to conduct the second stage of data collection.

In the second stage, a field survey was conducted, in which rural properties and offices of experts in 8 soybean-producing municipalities were visited (Figure 6). In total 4,360 km were covered, $640 \mathrm{~km}$ of which on unpaved highways.

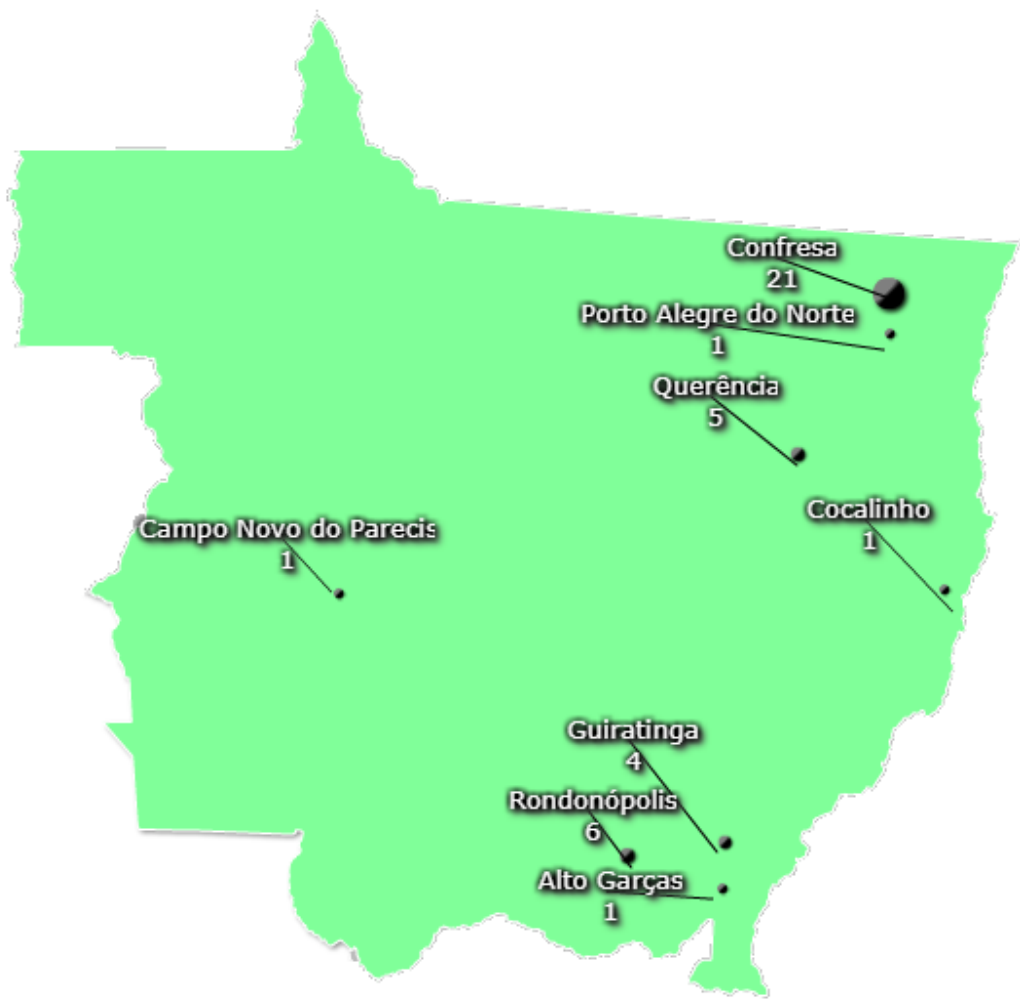

Figure 6. Municipalities visited for data collection. Source: Results of research (2018).

When contacting experts and producers, they were given information regarding the reason and purpose of the study, clarifying that answering the questionnaire was not mandatory, and instructions were given on how to compare the criteria concerning the general objective. In the questionnaire, respondent identification was not mandatory, and participants were asked to perform several comparisons between the factors influencing soybean decision-making regarding production, marketing, and logistics, which accounted for a total of 84 questions. Eventually, we reach the sample presented in this article of 21 farmers and 19 experts. 


\subsection{Data analysis}

After the interviews, the answers were entered into spreadsheets using Microsoft Excel ${ }^{\circledR}$. The respondents provided different answers, which is normal in a scenario of multiple decisions. Thus, decision-making is considered the highest number of answers for each criterion. Therefore, if in the comparison between criterion $A$ and $B$, most respondents considered criterion $A$ more important using the Saaty scale, than the criterion was selected for the parity matrix score.

However, even after the criteria were defined, it was necessary to establish their degree of importance. The geometric mean considered by Saaty (1980) was used to define a mean value for a group decision. The geometric means are calculated according to Equation 4.

$$
\left(\prod_{i=1}^{n} a_{i}\right)=\sqrt[n]{a_{1} a_{2} \cdots a_{n}}
$$

where:

$\mathrm{n}=$ number of respondents

$a_{1}, a_{2}, \ldots . a_{n}=$ equal answer from each respondent

For comparison purposes, the respondents were divided into two groups: (i) experts and (ii) producers. This decision was made because they were distinct groups, sometimes with conflicting interests. In this manner, it was possible to have a reference understanding of how producers view the decision-making process and how experts believe this process occurs, which would greatly contribute to the discussion of this study.

After defining the weights, a paired comparison was required, using the proposed model. The model was resolved with Expert Choice ${ }^{\circledR}$ v.11 software, which is used in multicriteria decision problems.

The proposed model was created in the software, and the weights were inserted considering the scale of importance and the answers provided in the questionnaire. After that, the model was checked for inconsistencies and required adjustments, without changing the meaning of the answers provided. Finally, the model was processed. The results are discussed in the following section.

\section{Results and Discussion}

The primary objective of this study was to investigate how rural production, marketing, and logistics influence the decision-making process of soybean producers in Mato Grosso considering a multicriteria decision analysis.

The three key criteria were determined in the first stage of this study after a literature review. The subcriteria under the marketing criterion included price, reliability, and negotiation, whereas the subcriteria under rural production were climate, cost of inputs, agricultural financing, and soil quality. Finally, the subcriteria under logistics were transport and storage.

The AHP model was used to determine the relative importance of each element in the hierarchy. All elements from one level were compared with other elements from the same level, concerning an element from a higher level.

Table 3 shows the results of the paired comparison, with the normalized weights of all three criteria and nine subcriteria and the perception of the two groups of respondents (experts and producers). 
Table 3. Summarized priorities and classifications for the criteria and subcriteria.

\begin{tabular}{|c|c|c|c|}
\hline \multirow{2}{*}{ Criteria/Subcriteria } & Producers & Experts & Overall \\
\hline & Weigths (Ranking) & Weigths (Ranking) & Weigths (Ranking) \\
\hline Marketing & $0.229(2)$ & $0.271(2)$ & $0.293(2)$ \\
\hline Price & $0.691(1)$ & $0.717(1)$ & $0.627(1)$ \\
\hline Negotiation & $0.218(2)$ & $0.195(2)$ & $0.280(2)$ \\
\hline Reliability & $0.091(3)$ & $0.088(3)$ & $0.094(3)$ \\
\hline Logistics & $0.075(3)$ & $0.085(3)$ & $0.067(3)$ \\
\hline Transport & $0.833(1)$ & $0.857(1)$ & $0.833(1)$ \\
\hline Storage & $0.167(2)$ & $0.143(2)$ & $0.167(2)$ \\
\hline Rural Production & $0.696(1)$ & $0.644(1)$ & $0.641(1)$ \\
\hline Climate & $0.575(1)$ & $0.590(1)$ & $0.556(1)$ \\
\hline Agricultural financing & $0.236(2)$ & $0.247(2)$ & $0.293(2)$ \\
\hline Cost of inputs & $0.135(3)$ & $0.107(3)$ & $0.100(3)$ \\
\hline Soil quality & $0.054(4)$ & $0.056(4)$ & $0.050(4)$ \\
\hline
\end{tabular}

Source: Results of research (2018)

The weights resulted from AHP analysis using Expert Choice v.11 ( ) are discussed by each criterion and subcriteria in the next sections.

\subsection{Logistics}

As observed in the literature review, several studies address logistics deficiencies in Brazil; among them, the study conducted by Arvor et al. (2010), which points out that efforts have been made to minimize such deficiencies since the 1970s with the National Integration Programs (PINs); pluriannual development plans (PPAs); the "Brazil in Action" (Brasil em Ação) Program in force between 1996 and 1999; the "Advance, Brazil" (Avança Brasil) Project between 2000 and 2003; and the Growth Acceleration Program (Programa de Aceleração do Crescimento, PAC) between 2007 and 2017.

The logistics criterion presented the lowest degree of importance in decision-making to both the experts (0.085) and producers (0.075); in this scenario, the transportation subcriterion had the greatest relevance in the decision of both groups: 0.833 among the experts and 0.857 among the growers (Table 3).

\subsection{Transportation}

The concern of experts and producers was owing to the lack of availability of different types of transportation systems and the high cost of transportation both to receive inputs and distribute the soybeans produced in Mato Grosso. This result supports the importance of transportation systems for the soybean complex, as reported in the studies conducted by Garrett et al. (2013); Vilhena \& Ribeiro (2015); Oliveira et al. (2016).

The field survey indicates that under the logistics criteria, transportation is a subcriteria of relevant importance in decision-making because the costs of receiving agricultural inputs are inversely proportional to the type of road paving, road quality, and distance to the place where the agricultural inputs must be delivered. In other words, poor road conditions (unpaved and pitted) and long distances for the delivery of agricultural inputs lead to increased costs of transport, and consequently, higher soybean cost (Garrett et al., 2013). 
In principle, transportation will have a greater impact on producers for the delivery of agricultural inputs and a smaller impact on soybean distribution, as the costs are incurred to the buyer. Trading companies define the amounts paid per ton with transport agencies, depending on soybean supply and demand and the availability of transportation systems and trucks (Kussano \& Batalha, 2012; Martins et al., 2005).

Despite this situation, producers and experts have been unable to establish the importance of transportation because the cost of receiving the inputs is included in the cost of the product itself, which is linked to the production criteria (Goldsmith, 2008). Perhaps in a future study, it will be interesting to check the role of infrastructure instead of only transport costs. Reis et al. (2020) demonstrate that logistics infrastructure has a huge impact on the international soybean trade.

\subsection{Storage}

The subcriteria storage is still considered a logistics challenge to be solved. However, experts and producers indicate that it is a subcriteria of a smaller impact on the decision-making process, with weights of 0.143 and 0.167 , owing to the recent growth in static storage capacity in the State of Mato Grosso.

Indeed, the investments made in warehouses have resulted in improvements in soybean storage conditions and capacity in Mato Grosso. It can be observed in reduced traffic jams on the roads and particularly in warehouse reception yards (Vieira \& Dalchiavon, 2018). Indeed, currently, operators are using a delivery schedule and a bigger storage area to allow the movement of more fluid of the grains during the harvest.

Although the small importance is given to soybean storage, this cannot be interpreted as a comfortable situation for producers because the ratio between agricultural production and static capacity is relatively high, around 1.25 (Maia et al., 2013). The current static storage capacity of Mato Grosso is 37.9 million tons of grains (Brasil, 2019), 95\% of which is for the private enterprise and $63 \%$ is in the rural area (Maia et al., 2013), facilitating management and organization among producers and warehouse managers.

\subsection{Marketing}

Marketing was the criterion that presented the second-highest impact on the decision made by both experts $(0.271)$ and producers $(0.229)$. It means that soybean producers do not perceive the importance of marketing in the decision-making process and delegate to other market agents the responsibility for the distribution of their soybean produce (Fountas et al., 2006; Singh et al., 2016).

\subsection{Price}

Experts (0.717) and producers (0.691) also highlighted the strong importance of the subcriteria price, which can be understood as a consequence of the need to ensure the subsistence of the activity (Singh et al., 2016) considering that the costs of acquisition of inputs and transport have a direct impact on the activity's profit margin (Garrett et al., 2013; Celio et al., 2014). In the soybean marketing process, producers end up as price takers (Oliveira \& Pereira, 2009; Gonçalves et al., 2014). The prices determined for the purchase of inputs and the sale of soybean present great relevance for the decision-making. 
This scenario confirms the theory proposed by Goldsmith (2008) for the difference in prices received by farmers in Brazil. According to this author, even with prices set by the Chicago Stock Exchange, a difference is observed between the amounts paid to producers from different regions of Brazil. In Sorriso, for instance, one of the leading soybean-producing municipalities in Mato Grosso, the amount paid to soybean producers is $27 \%$ lower than the amount set by the Chicago Stock Exchange (Goldsmith, 2008).

\subsection{Negotiation}

The experts considered the subcriteria negotiation to be of moderate importance (0.195), whereas the producers expressed a low degree of importance (0.091). Both groups of decisionmakers do not value the real importance of negotiation in this process. Negotiation is responsible for establishing conditions of purchase and sale that make the business attractive to both buyers and sellers, minimizing conflicts of interest, and reducing win-lose transactions to the detriment of transactions in which everyone fulfills their respective interests (Coelho, 2000; Dias, 2008).

The experts' perception can be explained by the fact that agronomists, input suppliers, and financial agents are direct or indirect service providers and depend on the producer's business. Conversely, negotiation has small importance to producers in the decision-making process because it represents the crystallization of a single commercial culture that frequently uses the same transaction channel, same companies, and same delivery conditions. The producers' ability to impose their will and set the amount to be paid is limited because the influence of trading companies on business conditions-to the detriment of producers-goes beyond the agricultural dimension (Colsera \& Henz, 2000).

\subsection{Reliability}

The subcriterion reliability presented small importance in the experts' decision-making $(0.088)$ and moderate importance $(0.218)$ to producers. This perception is because global soybean buyers who operate in the Mato Grosso market are large and consolidated, giving a perception of security to decision-makers in their relationship of buying and selling soybean and agricultural inputs (Turzi, 2011).

Bartering transactions with large trading companies such as ADM, Amaggi, Bunge, Cargill, Dreyfuss, and others allow better control of risks related to the soybean sale price and the purchase price of inputs used in soybean production (Instituto Mato-grossense de Economia Agropecuária, 2019).

In bartering (exchange), the trading company (or reseller) agrees to supply the inputs required for soybean planting and crop development and, in return, the producer agrees to give back part of the production as payment at the time of harvest (Kunitake \& Mota, 2016; Silva \& Lapo, 2012). This model of negotiation involves trust among the parties involved and aims for their mutual strengthening in the activity: the trading company secures the supply of the necessary soybean for its business, and conversely, the producer secures production financing (Turzi, 2011).

The bartering system offered by trading companies and resellers, according to the Instituto Mato-grossense de Economia Agropecuária (2019), in the 2019/2020 harvest, presented a considerable increase in the share of soybean crop financing, accounting for $47 \%$ of funding (equivalent to BRL 10.5 billion), attesting to the reliability between the partners. 
The availability of different ways to finance soybean production has an impact not only on the decision regarding the aspects under the marketing criteria but also on the decision related to the rural production criterion.

\subsection{Rural Production}

The criterion rural production was considered by both experts (0.644) and producers ( 0.666$)$ as the most important factor in the decision-making process. This criterion has a strategic nature as it involves the selection of a production financing system (own, bartering, or public financing), the technology to be adopted (direct or conventional sowing), the type of seed to be used (genetically modified or conventional), selection of one, two, or three harvests per crop year (through crop-livestock integration); if the production will be commercialized in advance or after the harvest. All of these are decisions that need to be made to maximize profitability (Carauta et al., 2017).

\subsection{Climate}

The subcriteria climate was the most important in the decision-making process to both experts $(0.590)$ and producers $(0.575)$. This can be particularly explained by the sensitivity of soybean production to the effects of climate (Arvor et al., 2010). The State of Mato Grosso is characterized by high temperatures and low, concentrated rainfall (Féres et al., 2011); a lack of rain during the sowing period or excessive rain during the harvest would both cause losses (Pires et al., 2016).

An increase in temperature owing to global warming harms soybean production, and according to Féres et al. (2011), such losses may reach BRL 7.4 billion by 2020 .

\subsection{Agricultural financing}

For decision-making, the subcriteria agricultural financing showed high divergence when comparing the views of experts (0.247) and producers (0.054).

This divergence is explained by the fact that the producers lack capital and have no other option; hence, they are forced to use financing to ensure the continuity of their agricultural activities (Instituto Mato-grossense de Economia Agropecuária, 2019). Therefore, contracting debt to fund production or invest in it through agricultural financing is indispensable as the producers have insufficient cash for the purchase and payment of inputs, and the decision to use such resources becomes intrinsic to soybean production (Goldsmith, 2008).

Conversely, experts do not consider agricultural financing as a crucial tool for the continuity of soybean production and in their view. It can be replaced with other types of funding. So that, it can be contracted only as needed and/or when available.

Agricultural financing and bartering are commonly used to buy inputs because their use is expensive. According to Instituto Mato-grossense de Economia Agropecuária (2019), the amount of capital to cover the cost of the 2019/2020 harvest in Mato Grosso was BRL 22.5 billion.

\subsection{Cost of inputs}

In this context, experts (0.107) and producers (0.135) answered that the cost of agricultural inputs has a low relevance in decision-making, contrary to the results found in the study 
conducted by Singh et al. (2016). Garrett et al. (2013) reported an inconsistency, stating that the costs of inputs have a direct impact on agricultural profit. These authors also reported that, for a producer to maximize profits, the optimal use of inputs must be made rationally.

Regarding the cost of inputs, Goldsmith (2008) also notes that it has had solid growth in recent years, whereas proportional revenue has not been obtained. The increase in the cost of inputs is mainly attributed to increased costs of fertilizers, fungicides, and insecticides (Goldsmith, 2008; Instituto Mato-grossense de Economia Agropecuária, 2019).

\subsection{Soil Quality}

Finally, the subcriterion soil quality also showed high divergence in terms of importance in decision-making to experts (0.056) and producers (0.236). Soil is observed by many experts and producers as the most important agricultural asset as it directly affects productivity, the number of pesticides used, and the availability of water by retention (Yost et al., 2017).

According to the experts, soil quality has little importance in decision-making as it is possible to recover its quality by using different systems of direct sowing and crop rotation (Congreves et al., 2015), or using fertilizers (Choudhary et al., 2018). However, both solutions would involve additional costs.

In the view of producers, soil quality is directly associated with increased productivity and profitability of soybean crop (Lacerda et al., 2015; Santos et al., 2008) and with the investments required to recover soil health through organic matter replacement, acidity correction, improved fertility (particularly nitrogen $\mathrm{N}$, phosphorus $\mathrm{P}$, and potassium $\mathrm{K}$ ), soil drainage, and other actions that require time, and financial and technological resources (Goldsmith, 2008; Congreves et al., 2015; Lacerda et al., 2015; Choudhary et al., 2018).

\section{Conclusions}

Soybean is the main commodity produced in Brazil; the country is the world's leading soybean exporter. With several uses in human food and animal feed products, soybean has a critical role in the human diet, and it is strategic considering the estimated increase in the global population.

This study developed a hierarchical decision model based on the AHP theory. Based on the view of experts and producers, it sought to determine the weights of factors that influence the decision for planting and the development of the soybean chain. Using the State of Mato Grosso as a reference, the largest producer in Brazil, it was possible to obtain important results about the decision-making process.

Considering the criteria, it is possible to state that, for agricultural producers and experts, soybean is the most important production chain in Brazil, particularly in the Central-West region.

Among the several factors that can affect the production decision, this study concluded that the aspects related to inputs, agricultural financing, climate, and soil quality highly influence the decision factor-that is, factors related to rural production (accounting for approximately $70 \%$ of the model). It means that both producers and experts acknowledge that producers are concerned about achieving good productivity levels at low operating costs as these factors directly affect their profit margins.

Another relevant result is that logistics, although seen as strategic for agribusiness in the country, is not considered of great impact on the decision process of producers. The process of selling the soybean production is based on local prices; therefore, the buyer has to hire a transportation service, which is included in the margin between the sale at local prices and 
the export sale at prices set by the Chicago Stock Exchange, or in the cost of the inputs for the production of agro-industrial items.

Finally, a great impact from the trading companies was observed on the soybean chain, and on the decision model, which could not be more conclusive owing to the non-participation of trading companies in this study. This is one of the main limitations of this study. However, this limitation did not affect the exploratory nature of this investigation, which can be used to develop future studies, which could also include census data.

\section{Acknowledgments}

This study was conducted with support of the Coordination for the Improvement of Higher Education Personnel (CAPES)—Financing Code 001; and from the Federal Institute of Education, Science and Technology of Mato Grosso (IFMT).

\section{References}

Abraham, E. R., Reis, J. G., Vendrametto, O., Costa Neto, P. L. O., Toloi, R. C., Souza, A. E., \& Morais, M. O. (2020). Time series prediction with Artificial Neural Networks: an analysis using Brazilian soybean production. Agriculture, 10(10), 475.

Arvor, D., Gonçalves, M. M., Moine, S., \& Vitter, M. (2010). The evolution of the soybean industry in Mato Grosso. Confins, 10.

Associação Nacional para Difusão de Adubos - ANDA (2017). Anuário estatístico do setor de fertilizantes. São Paulo: Associação Nacional para Difusão de Adubos.

Brasil. Companhia Nacional de Abastecimento - CONAB (2019). Série histórica da armazenagem. Site Oficial Conab, Brasília. Retrieved in 2020 October 21, from https://www.conab.gov.br/ armazenagem/serie-historica-da-armazenagem.

Brasil. Companhia Nacional de Abastecimento - CONAB (2020). Séries históricas de área plantada, produtividade e produção, relativas às safras 1976/77 a 2019/20 de soja. Site Oficial Conab, Brasília. Retrieved in 2020 October 21, from https://www.conab.gov.br/info-agro/safras/ serie-historica-das-safras?start=30.

Carauta, M., Libera, A. A. D., Hampf, A., Chen, R. F. F., Silveira, J. M. F. J., \& Berger, T. (2017). On-farm trade-offs for optimal agricultural practices in Mato Grosso, Brazil. Revista de Economia e Agronegócio, 15(3), 299-322.

Cavalett, O., \& Ortega, E. (2009). Emergy, nutrients balance, and economic assessment of soybean production and industrialization in Brazil. Journal of Cleaner Production, 17(8), 762-771.

Celio, E., Flint, C. G., Schoch, P., \& Grêt-Regamey, A. (2014). Farmers' perception of their decisionmaking in relation to policy schemes: a comparison of case studies from Switzerland and the United States. Land Use Policy, 41, 163-171.

Choudhary, M., Panday, S. C., Meena, V. S., Singh, S., Yadav, R. P., Mahanta, D., Mondal, T., Mishra, P. K., Bisht, J. K., \& Pattanayak, A. (2018). Long-term effects of organic manure and inorganic fertilization on sustainability and chemical soil quality indicators of soybean-wheat cropping system in the Indian mid-Himalayas. Agriculture, Ecosystems \& Environment, 257, 38-46.

Coelho, C. N. (2000). Negociações agrícolas: existe uma saída? Revista de Política Agrícola, 944), 46-49.

Colsera, L., \& Henz, R. (2000). A retomada das negociações agrícolas na OMC. Revista de Política Agrícola, 9(4), 10-45. 
Congreves, K. A., Hayes, A., Verhallen, E. A., \& Van Eerd, L. L. (2015). Long-term impact of tillage and crop rotation on soil health at four temperate agroecosystems. Soil \& Tillage Research, 152, 17-28.

Contini, E. (2010). Brazilian agriculture, its productivity and change. In Å. Barklund, (Ed.), Food Security and the Futures of Farms: 2020 and toward 2050 (pp. 35-38). Falkenberg: The Royal Swedish Academy of Agriculture and Forestry.

Dias, S. W. (2008). Estilos de negociação nas transações comprador-vendedor: uma aplicação do instrumento TKI® (Masters thesis). Universidade de São Paulo, São Paulo.

Féres, J., Reis, E., \& Speranza, J. S. (2011). Impacto das mudanças climáticas no setor agrícola brasileiro. In R. Seroa da Motta, J. Hargrave, G. Luedemann, \& M. B. S. Gutierrez (Orgs.), Mudança do clima no Brasil: Aspectos econômicos, sociais e regulatórios. Ipea.

Fountas, S., Wulfsohn, D., Blackmore, B. S., Jacobsen, H. L., \& Pedersen, S. M. (2006). A model of decision-making and information flows for information-intensive agriculture. Agricultural Systems, 87(2), 192-210.

Garrett, R. D., Lambin, E. F., \& Naylor, R. L. (2013). Land institutions and supply chain configurations as determinants of soybean planted area and yields in Brazil. Land Use Policy, 31, 385-396.

Goldsmith, P. D. (2008). Soybean production and processing in Brazil. In L. A. Johnson, P. J. White, \& R. Galloway (Eds.), Soybeans: Chemistry, production, processing, and utilization (pp. 773-798). Urbana: AOCS Press.

Goldsmith, P. D., \& Hirsch, R. (2006). The Brazilian soybean complex. Choices: The Magazine of Food, Farm, and Resource Issues, 21(2), 97-104.

Gonçalves, D. N. S., Gonçalves, C. de M., Assis, T. F., \& Silva, M. A. (2014). Analysis of the difference between the euclidean distance and the actual road distance in Brazil. Transportation Research Procedia, 3, 876-885.

Granemann, S., \& Figueiredo, A. (2013). Logística aplicada à exportação - instrumento de competitividade. Revista Brasileira de Economia de Empresas, 1(1), 51-62.

Instituto Brasileiro de Geografia e Estatística - IBGE. (2012). Censo agropecuário 2006: Brasil, grandes regiões e unidades da federação - segunda apuração. Rio de Janeiro: IBGE.

Instituto Brasileiro de Geografia e Estatística - IBGE. (2020a). Cidades e estados: Mato Grosso. Retrieved in 2020 October 24, from https://www.ibge.gov.br/cidades-e-estados/mt.html

Instituto Brasileiro de Geografia e Estatística - IBGE. (2020b). Produção agrícola municipal. Retrieved in 2020 October 22, from https://sidra.ibge.gov.br/Tabela/1612

Instituto Mato-grossense de Economia Agropecuária - IMEA. (2019). Composição do funding do custeio da soja para safra 2019/20 em Mato Grosso. Cuiabá: IMEA.

Kunitake, A., \& Mota, E. P. (2016). Análise comparativa do pagamento de insumos da produção da soja no estado de Mato Grosso. Revista IPecege, 2(4), 24-41.

Kurlavičius, A. (2009). Sustainable agricultural development: knowledge-based decision support. Technological and Economic Development of Economy, 15(2), 294-309.

Kussano, M. R., \& Batalha, M. O. (2012). Custos logísticos agroindustriais: avaliação do escoamento da soja em grão do Mato Grosso para o mercado externo. Gestão \& Produção, 19(3), 619-632.

Lacerda, J. J. J., Resende, Á.V., Furtini Neto, A. E., Hickmann, C., \& Conceição, O. P. (2015). Adubação, produtividade e rentabilidade da rotação entre soja e milho em solo com fertilidade construída. Pesquisa Agropecuária Brasileira, 50(9), 769-778.

Lipinski, B., Hanson, C., Lomax, J., Kitinoja, L., Waite, R., \& Searchinger, T. (2013). Reducing Food Loss and Waste. Washington, DC: World Resources Institute. 
Maia, G. B. S., Pinto, A. R., Marques, C. Y. T., Lyra, D. D., \& Roitman, F. B. (2013). Panorama da armazenagem de produtos agrícolas no Brasil. Revista do BNDES, 40, 161-193.

Martins, R. S., Rebechi, D., Prati, C. A., \& Conte, H. (2005). Decisões estratégicas na logística do agronegócio: compensação de custos transporte-armazenagem para a soja no estado do Paraná. Revista de Administração Contemporânea, 9(1), 53-78.

Oliveira, D. L., \& Pereira, S. A. (2009). Análise do processo decisório no agronegócio: abordagem na cadeia de valor da soja. Gestão e Sociedade, 2(4), 1-24.

Oliveira, F. C., Coelho, P. H. M. C., \& Sousa Neto, M. S. N., Andre, A. C. S., Santos, F. L. S., Oliveira, J. P. M., Oliveira, B. S., Teixeira, I. R. T., \& Campos, A. J. C. (2016). Logistics and storage of soybean in Brazil. African Journal of Agricultural Research, 11, 3261-3272.

Pires, G. F., Abrahão, G. M., Brumatti, L. M., Oliveira, L.J. C., Costa, M. H., Liddicoat, S., Kato, E., \& Ladle, R.J. (2016). Increased climate risk in Brazilian double cropping agriculture systems: implications for land use in Northern Brazil. Agricultural and Forest Meteorology, 228-229, 286-298.

Puchalsky, W., Ribeiro, G. T., Veiga, C. P., Freire, R. Z., \& Coelho, L. S. (2018). Agribusiness time series forecasting using Wavelet neural networks and metaheuristic optimization: an analysis of the soybean sack price and perishable products demand. International Journal of Production Economics, 203, 174-189.

Raucci, G. S., Moreira, C. S., Alves, P. A., Mello, F. F. C., Frazão, L. A., Cerri, C. E. P., \& Cerri, C. C. (2015). Greenhouse gas assessment of Brazilian soybean production: a case study of Mato Grosso State. Journal of Cleaner Production, 96, 418-425.

Reis, J. G. M., Amorim, P. S., Cabral, J. A. S. P., \& Toloi, R. C. (2020). The impact of logistics performance on Argentina, Brazil, and the US soybean exports from 2012 to 2018: a gravity model approach. Agriculture, 10(8), 338.

Reis, J. G. M., Vendrametto, O., Naas, I. A., Costabile, L. T., \& Machado, S. T. (2016). Avaliação das estratégias de comercialização do milho em MS Aplicando o Analytic Hierarchy Process (AHP). Revista de Economia e Sociologia Rural, 54(1), 131-146.

Reis, S. A., \& Leal, J. E. (2015). A deterministic mathematical model to support temporal and spatial decisions of the soybean supply chain. Journal of Transport Geography, 43, 48-58.

Rose, D. C., Sutherland, W. J., Parker, C., Lobley, M., Winter, M., Morris, C., Twining, S., Ffoulkes, C., Amano, T., \& Dicks, L. V. (2016). Decision support tools for agriculture: towards effective design and delivery. Agricultural Systems, 149, 165-174.

Rupnik, R., Kukar, M., Vračar, P., Košir, D., Pevec, D., \& Bosnić, Z. (2018). AgroDSS: a decision support system for agriculture and farming. Computers and Electronics in Agriculture, 161, 260-271.

Saaty, T. L. (1980). The Analytic Hierarchy Process: planning, priority setting, resource allocation. New York: McGraw-Hill International Book Company.

Saaty, T. L. (2008). Decision making with the analytic hierarchy process. International Journal of Services Sciences, 1, 83-98.

Santos, F. C., Novais, R. F., Neves, J. C. L., Foloni, J. M., Albuquerque Filho, M. R., \& Ker, J. C. (2008). Produtividade e aspectos nutricionais de plantas de soja cultivadas em solos de cerrado com diferentes texturas. Revista Brasileira de Ciência do Solo, 32(5), 2015-2025.

Silva, F. P., \& Lapo, L. E. R. (2012). Modelos de financiamento da cadeia de grãos no Brasil. In 2a Conferência em Gestão de Risco e Comercialização de Commodities. São Paulo: BM\&FBOVESPA. 
Singh, C., Dorward, P., \& Osbahr, H. (2016). Developing a holistic approach to the analysis of farmer decision-making: implications for adaptation policy and practice in developing countries. Land Use Policy, 59, 329-343.

Soares, A. F. (2016). Requisitos ambientais no mercado de soja brasileiro: descrição e avaliação de impacto (PhD dissertation). Escola Superior de Agricultura Luiz de Queiroz, Universidade de São Paulo, Piracicaba.

Teixeira, M. D. J., Faria, A. M. M., \& Zavala, A. A. (2013). Emissões antrópicas de gases de efeito estufa (GEE) e referenciais para política de mitigação das emissões em Mato Grosso (Brasil). Revista Eletrônica Documento Monumento, 10, 307-323.

Toloi, R. C., Gunes, A. C. R. S. L., Toloi, M. N. V., Reis, J. G. M., Bonilla, S. H., and Freitas, M. J. (2018). Main variables that are influenced by the anthropic activity resulting from the soybean production in the municipalities of Mato Grosso. Independent Journal of Management \& Production, 9(5), 607-622.

Tongeren, F., Banse, M., Kavallari, A., Bartelings, H., Meijl, H., llicic-Komorowska, J., Lampe, M., \& Junker, F. (2014). Fertiliser and biofuel policies in the Global Agricultural Supply Chain (OECD). OECD Food, Agriculture and Fisheries Working Papers, 69, 1-81.

Turzi, M. (2011). The soybean republic. Yale Journal of International Affairs, 6, 59-68.

United Nations Department of Economics and Social Affairs - UN DESA. (2019). World population prospect. Retrieved in 2020 October 21, from https://www.un.org/development/desa/ publications/world-population-prospects-2019-highlights.html

United States Department of Agriculture - USDA. (2020). Oilseeds: World Markets and Trade. Washington, DC: United States Department of Agriculture. Retrieved in 2020 October 21, from https://apps.fas.usda.gov/psdonline/circulars/oilseeds.pdf

Vieira, R. A., \& Dalchiavon, F. C. (2018). Custos e viabilidade da implantação de uma unidade armazenadora de grãos no Mato Grosso. Revista IPecege, 4(2), 7-15.

Vilhena, L. C. T., \& Ribeiro, P. C. C. (2015). Stock management and vendor managed inventory: a case study in a supermarket network. Revista Produção e Desenvolvimento, 1(1), 50-59.

Yost, M. A., Kitchen, N. R., Sudduth, K. A., Sadler, E. J., Drummond, S. T., \& Volkmann, M. R. (2017). Long-term impact of a precision agriculture system on grain crop production. Precision Agriculture, 18, 823-842.

Zhu, Q., \& Sarkis, J. (2004). Relationships between operational practices and performance among early adopters of green supply chain management practices in Chinese manufacturing enterprises. Journal of Operations Management, 22(3), 265-289. 